\title{
Intelligence Offices in the Habsburg Monarchy*
}

\author{
Anton Tantner
}

\section{Introduction}

In the seventeenth century, the great European metropolises of Paris and London saw the establishment of so-called intelligence offices, which served as places of institutionalised information brokerage and were to promote the exchange of goods, real estate and work opportunities. ${ }^{1}$ The first known institution of this kind, the Bureau d'adresse, was established near Notre-Dame in Paris in 1630; it was created on the initiative of the physician Théophraste Renaudot (1586-1653), a native of Montpellier, and undertook a number of different tasks: it acted not only as a sales agency and brokered real estate and work, but beyond that it served as a pawnbroker, a place of medical care for the poor, and as a venue for academic lectures, the conférences du Bureau d'adresse. All those who presented a request there could have it entered into a register for a fee of three sous; for the same sum, information was provided from the register. From time to time, excerpts from the register were published in the form of advertisements in its own advertising paper, the Feuille du Bureau d'adresse; from 1631, the information expert Renaudot published articles on political events in his newspaper, the Gazette. ${ }^{2}$ In London, on the other hand, comparable

* Translated by Brita Pohl; www.bricolangue.at.

1 On information offices in general, see Astrid Blome, 'Offices of Intelligence and Expanding Social Spaces', in The Dissemination of News and the Emergence of Contemporaneity in Early Modern Europe, ed. Brendan Dooley (Farnham: Ashgate, 2010), pp. 207-22 and Anton Tantner, Adressbüros im Europa der Frühen Neuzeit, Habilitation thesis (University of Vienna, 2011) $<$ http://phaidra.univie.ac.at/o:128115> [8/1/15]; the present text resulted from two projects funded by the Austrian Science Fund (P19826-Go8, Europäische Adressbüros in der Frühen Neuzeit)and theJubliäumsfonds of the Austrian National Bank(no.15275, Auskunftscomptoire und Adressbüros in der Habsburgermonarchie, 1750-1850).

2 Howard M. Solomon, Public Welfare, Science and Propaganda in Seventeenth Century France: The Innovations of Théophraste Renaudot (Princeton: Princeton University Press, 1972); Gilles Feyel, L'Annonce et la nouvelle. La presse d'information en France sous l'ancien régime (16301788) (Oxford: Oxford University Press, 2000), pp. 11-308; Justin Stagl, A History of Curiosity: The Theory of Travel, 1550-180o (London: Routledge, 1995), pp. 134-47; Gérard Jubert, ed., Père des Journalistes et Médecin des Pauvres. Théophraste Renaudot (1586-1653) (Paris: Honoré Champion, 2005).

(C) ANTON TANTNER, 2016 | DOI 10.1163/9789004277199_020

This is an open access chapter distributed under the terms of the Creative Commons Attribution-

Noncommercial-NoDerivatives 3.o Unported (CC-BY-NC-ND 3.0) License. 
institutions were founded from the mid-seventeenth century onward, which were known as 'intelligence' or 'registry' offices and mainly served to broker goods and domestic servants. They published advertisement papers and often established themselves near the Royal Exchange. ${ }^{3}$

These intelligence offices raise a number of questions, which, due to the scarcity of the sources identified so far, cannot yet be answered satisfactorily: what were the relations between information offices and traditional information brokers? Amongst the latter, especially concerning the placement of domestic servants, were the so-called servant agents, mostly elderly women who had specialist knowledge about domestic positions available in individual households, who were often accused of poaching domestics after having placed them in order to pocket a second brokering fee. How were the offices organised, were they state, city or-as was usually the case — privately administered, if licensed, institutions? Who frequented the information offices? Women, for example, were not accepted as customers in every case, as it seems on the whole that the institution of information offices in general was accompanied by a masculinisation of information brokerage, i.e. a squeezing out of women from this area of activity, which may already be identified during the seventeenth century. How did the interplay between information offices, and the brokering activities accomplished there, and other media in the urban area, work? Namely, what was the relationship between the advertisement papers sometimes published by the information offices and the institution of the penny post?

All these questions will stay relevant for future research; here, using archival and printed sources, I would like to attempt a description of the activities of largely unnoticed information offices in the example of the Habsburg Monarchy.

3 W.H. Beveridge, 'A Seventeenth-Century Labour Exchange', Economic Journal, 24 (1914), pp. 371-6; M. Dorothy George, 'The Early History of Registry Offices. The Beginnings of Advertisement', Economic Journal Economic History Supplement, 1 (1926-9), [January 1929], pp. 570-90; Michael Harris, 'Exchanging Information: Print and Business at the Royal Exchange in the Late Seventeenth Century', in The Royal Exchange, ed. Ann Saunders (London: London Topographical Society, 1997), pp. 188-97; Michael Harris, 'Timely Notices:The Use of Advertising and its Relationship to News during the Late Seventeenth Century', in News, Newspapers, and Society in Early Modern Britain, ed. Joad Raymond (London: Routledge, 1999), pp. 141-56; Karl Tilman Winkler, 'Die Zeitung und die Anfänge der Informationsgesellschaft. Wirtschaft, Technologie und publizistischer Markt in London 1665-1740', in 40o Jahre Zeitung. Die Entwicklung der Tagespresse im internationalen Kontext, ed. Martin Welke and Jürgen Wilke (Bremen: edition lumière, 2008), pp. 139-75. 


\section{Seventeenth Century Projects}

\section{The Viennese Fragstuben Project of Johannes Angelus de Sumaran}

In Vienna, the opportunity to establish a comparable institution arose only a few years after the opening of the Paris Bureau d'adresse. The initiative came from a certain Johannes Angelus de Sumaran (also Juan Àngel de Zumaran), a language teacher who had been born in the Basque province of Guipúzcoa at the end of the sixteenth century, and about whom we have only scant biographical details. ${ }^{4}$ He came from a noble family and, after spells in Brussels, Ingolstadt and Munich, surfaced in Vienna in 1622, where he was listed in the university's register as "prof. linguarum". ${ }^{5}$ From about 1610 , he had taught Spanish, Italian and French as well as dancing; in the autumn of 1636, he petitioned to Archduke Leopold Wilhelm for the privilege, for himself and his family, for an offentliche fragstuben (public inquiry room). ${ }^{6}$ In his petition, which he signed as Professor Linguarum dieser Universitet in Wienn, he first pointed out that in many foreign countries and cities, there already were "certain taverns or public rooms". ${ }^{7}$ Anyone who wanted to buy or sell anything was able

4 For material on his biography, see Konnrad Schröder, Biographisches und bibliographisches Lexikon der Fremdsprachenlehrer des deutschsprachigen Raumes, Spätmittelalter bis 1800 , vol. 4 (Augsburg: Universität Augsburg, 1995), pp. 190-2; vol. 6 (Augsburg: Universität Augsburg, 1999), pp. 268-9; Katrin Wippich-Roháčkova, "Der Spannisch Liebende Hochdeutscher". Spanischgrammatiken in Deutschland im 17. und frühen 18. Jahrhundert (Hamburg: Buske Verlag, 2000), p. 85.

5 Götz Pölnitz, ed., Die Matrikel der Ludwig-Maximilians-Universität Ingolstadt-LandshutMünchen, part 1, vol. 2: Ingolstadt 1600-1650 (Munich: Lindauer, 1939), p. 238; Franz Gall and Hermine Paulhart, eds., Die Matrikel der Universität Wien, vol. 4: 1579/II-1658/59 (Vienna, Cologne, Graz, Böhlau in Komm., 1974), p. 115.

6 Barbara Bruzzone, 'Fremdsprachen in der Adelserziehung des 17. Jahrhunderts: Die Sprachbücher von Juan Angel de Sumarán', in Die Volkssprachen als Lerngegenstand im Mittelalter und in der frühen Neuzeit. Akten des Bamberger Symposions am 18. und 19. Mai 2001 (Berlin, New York: Walter de Gruyter, 2002), pp. 37-45, at 37; [Anonymous], 'Zur Geschichte des Wiener Fragamtes', in Wiener Communal-Kalender und städtisches Jahrbuch, 31 (1893), pp. 419-26. The documents quoted in this essay, which Karl Schrauf, an employee of the HausHof und Staatsarchiv, had found at the Vienna University archive, were untraceable in the 1980s according to Manfred Bobrowsky: Manfred Bobrowsky, Das Wiener Intelligenzwesen und die Lesegewohnheiten im 18. Jahrhundert, $\mathrm{PhD}$ thesis (University of Vienna, 1982), v. Thanks to Thomas Maisel (UAW), they were located again: UAW, Kodex Th 16: Acta Facultatis Theologicae, IV $1567-1666$, fos. $289 \mathrm{r}-291 \mathrm{a}^{\mathrm{r}}$; fos. $29 \mathrm{~b}^{\mathrm{v}}-292 \mathrm{~b}^{\mathrm{v}}$, entries of 27 October 1636 and 23 November 1636. The text passed down as a copy slightly deviates from the one printed in the Wiener Communal-Kalender, so Schrauf might have had the original documents at his disposal.

7 UAw, Kodex Th 16: Acta Facultatis Theologicae IV 1567-1666, fos. $291 \mathrm{a}^{\mathrm{r}}$. 
to register there and "ask for any things". In no more than "a quarter of an hour", they were able to learn whether their demand could be fulfilled. As Sumaran mentioned that he was "well experienced" in the use of such institutions, it may be assumed that he used them, among other things, to offer his services as a language teacher; as an explicit model he quoted Paris, where a Doctor Medicinae-i.e. Renaudot—-"has lately invented this".

The inquiry room was to serve first and foremost as a sales agency for movables and real estate. Six kreutzer were to be asked of each individual willing to buy or sell as a registration fee; women, too, were explicitly envisaged as users. Sumaran also suggested that the new institution might be used as a kind of registration office or information bureau about the residence and reputation of the city's inhabitants: by this means, one might get to know what kind of people were in the city, where they came from, "what their doings were, where they lived, and who they consorted with", and what brush they were tarred with. Also, work placements were to be brokered: people who wanted to be "promoted" would be able to have their names including their residence and skills registered, while the names and locations of "such gentlemen or ladies who desire such people" would also be registered. Other services included the brokering of lodgings: "When strangers arrive and need board or a furnished room for a time", it would be possible to allocate those to them. ${ }^{9}$

In addition, Sumaran suggested that this Fragstube might assume the function of a debating club, if not an academy: "all sorts of languages and free Arts" were to be practiced there, and a weekly discussion about some piece of news was to be held. Everybody - especially "skilful, well-travelled and well-read people"-should be able to have their say and not be laughed at by anyone. The 'discourse' was to be recorded and to appear in print afterwards. Also, the Fragstube might be regarded as a news exchange, where "all sorts of news were to be found and learned, as correspondence and particularities" from all sorts of places would be received there. ${ }^{10}$ The listed offers did not cover all services Sumaran thought to provide; "many other such useful services" would "benefit

8 UAW, Kodex Th 16: Acta Facultatis Theologicae IV 1567-1666, fos. 289v-29or: "gewisse tabernen oder öffentliche stuben; nach allen sachen fragen; in einer viertl stundt; woll erfahren"; "ein Doctor Medicinae dises neulich inventiret".

9 UAW, Kodex Th 16: Acta Facultatis Theologicae IV 1567-1666, fo. 29ov: "was ihr thuen und lassen sey, wo sie wohnen, undt mit wem sie sich aufhalten"; "promoviert"; "Herrn oder Frauen, die solliche leith begehren"; "Wan frembde leuth herkhomen undt wollten gern auf ein Zeit ein khost oder mobiliertes Zimmer haben". und freye künsten"; "geschikte, wollgeraiste undt belesene leüth"; "allerley Zeittungen zu erfindten und zu erfahren"; "correspondenzen und particularien". 
the common wealth", Sumaran explained; he only lacked the space to explain them all in detail.1

Invectives against traditional service brokers, however, take up a fair amount of space in Sumaran's proposal: his institution would enable the authorities to suppress "harmful profiteers" as well as "all sorts of wandering Jews and landlopers [vagabonds] who do not have a trade or are settled here"; in his information office, usury, as practiced otherwise by "Jews and Christians", was to have no place. ${ }^{12}$ In addition, his offer would eliminate intermediate trade and be directed against 'middlemen' and 'cheats'. ${ }^{13}$ Sumaran especially had it in for the harmful servant brokers - "a cover for all Evil" - at whose places all sorts of 'rabble' hung about and who came and went in the houses, enticing women, daughters and maids to accept a position and then quickly abandon it again. Their activities would be controlled, since the protocols Sumaran envisaged for those seeking employment left no place for the middleman, with "only a slip of paper", as he said, deposited at the bureau, serving as broker between the prospective employer and employee. ${ }^{14}$

Sumaran's proposal was refused because the Theological Faculty at the University of Vienna gave a negative verdict. It first questioned Sumaran's academic status as a language professor, as only those who taught Hebrew and Greek were allowed to claim it; and secondly, it claimed that disputes and disagreements were to be expected between members of the university and the superintendent of the Fragstube, and that the income generated from brokering would not benefit the state, but the superintendent. Another argument brought forward by the Faculty was that the agents traditionally engaged in brokerage would lose their income, which would lead to hatred and envy. Another concern was that the activity of the sales agency would lead to fraud, as potential sellers would be able to register under a false name. In any case, it was improbable that one single institution would be able to offer such a range of services; an office of inquiry like the one proposed was merely a chimera.

11 UAW, Kodex Th 16: Acta Facultatis Theologicae IV 1567-1666, fo. 291ar: "vill anderer dergleichen nutzbarkheiten"; "Fragstuben dem gemainen Wesen zu guetten khommen". UAw, Kodex Th 16: Acta Facultatis Theologicae IV 1567-1666, fo. 289v: "schedlich Partitamacher"; UAW, Kodex Th 16: Acta Facultatis Theologicae IV 1567-1666, fo. 29ov: "allerley herumbstertzende Juden, undt Landtlauffer, die khein Gewerb treiben oder alhie hausgesessen sein, abges [c] haft”; UAW, Kodex Th 16: Acta Facultatis Theologicae IV 15671666, fo. 29or.

13 UAW, Kodex Th 16: Acta Facultatis Theologicae IV 1567-1666, fo. 2919 : "Unterhandler and leitbetrieger".

14 UAW, Kodex Th 16: Acta Facultatis Theologicae IV 1567-1666, fo. 29ov-291ar: "ein dekhmantl alles Übels"; "gesindl"; "ein Zetl". 
And finally, the office of inquiry presented a danger to the soul, by the mere fact that in its rooms, servants would come into frequent contact with masters and ladies. In its refusal, the Faculty even went so far as to call the office of inquiry a 'breeding place of sin' (seminarium peccatorum).${ }^{15}$ Its hostile stance shows how offensive the Faculty found the prospective institution of a brokering place in which different classes of society would meet. In spite of complaints about traditional brokers, these were insufficient to establish the Fragstube as a desirable alternative; furthermore, and perhaps not least among the faculty's considerations, its ambition to adopt the tasks of an academy was perceived as a competition to the university. ${ }^{16}$

\section{Wilhelm von Schröder's Intelligentz-Werck}

50 years after Sumaran, in 1686, the cameralist Wilhelm von Schröder (1640-99) published the project of a so-called Intelligentz-Werck in his Fürstliche Schatzund Rent-Cammer. ${ }^{17}$ Schröder knew the office of intelligence established at the London Exchange from his journeys to England (166o and 1678-81), and also referred to it; the Intelligenzwerk, however, was conceived to be much more comprehensive, as it was to help establish "a general market" in all hereditary lands of the Habsburg monarchy, "where everyone, within a quarter of an hour, could learn about everything that was on sale in all these lands, and where it was to be found, without travelling or sending messengers". Thus it would be possible to establish "good order in trade", which consisted in craftsmen finding traders to buy their products without having to carry them from

\footnotetext{
15 UAW, Kodex Th 16: Acta Facultatis Theologicae IV 1567-1666, fo. 292a ${ }^{\mathrm{r}-\mathrm{v}}$.

16 Cf. Blome, 'Offices of Intelligence' pp. 207-22, at 215-17.

17 On Schröder, see amongst others H.v. Srbik, 'Wilhelm von Schröder. Ein Beitrag zur Geschichte der Staatswissenschaften', Sitzungsberichte der kais. Akademie der Wissenschaften. Philosophisch-historische Klasse, 164.1 (1910); W. Halder, 'Schröder, Johann Wilhelm Freiherr v', $N D B$, vol. 23 (2007), pp. 577-8; Felix Czeike, Historisches Lexikon Wien in fünf Bänden (Vienna: Kreymayr \& Scheriau, 1992-7), vol. 5, p. 147, lemma 'Schröder (Schroeder) Wilhelm Frh. v.; cf. also the following accounts of the Intelligenzwerk project: Bobrowsky, Intelligenzwesen, pp. 22-7 and Friedrich Huneke, 'Sozialdisziplinierung, Lektüre und gesellschaftliche Erfahrung im Vergleich. Das Intelligenzblatt und die "Lippischen Intelligenzblätter" (1767-1799)', in Pressewesen der Aufklärung. Periodische Schriften im alten Reich, ed. Sabine Doering-Manteuffel, Josef Mancal and Wolfgang Wüst (Berlin: Akademie Verlag, 2001), pp. 210-44, at 214-5; Martin Gierl, 'Zeitschriften-Stadt-InformationLondon-Göttingen-Aufklärung', in Jenseits der Diskurse. Aufklärungspraxis und Institutionenwelt in europäisch komparativer Perspektive, ed. Hans E. Bödeker and Martin Gierl (Göttingen: Vandenhoeck \& Ruprecht, 2007), pp. 243-64, at 247-8.
} 
door to door, and "lose time with walking". ${ }^{18}$ The present state of things was far from this ideal, as it often happened that a craftsman finished a piece of work which was precisely what a potential client needed, but which he did not know how to find and therefore had to expend time searching for it. Also, many people in the country did not know that there was a demand for their products in the city, which is why they gave their wares to middlemen—Vorkäuffer - who contributed to price increases: "Sending messengers, item commissioning ... makes a thing expensive". "Newly-arrived strangers", too, suffered from their lack of knowledge, as they often looked for accommodation or services in vain, and were, if at all, referred to middlemen who brought them "more harm and mischief than good". 19

The new institution was to address another shortcoming, namely the lack of suitable servants, which was said to lead to masters having to pay them too high a wage; instead of the brokers who were tolerated without supervision, the Intelligenzwerk was to take over the placement of servants and would, in addition, install a separate court for them, where they would have to register. ${ }^{20}$ Once again, the delivery of police services was contemplated in connection with an intelligence office.

Schröder wanted to organise his Intelligenzwerk along the lines of the postal services: in all the hereditary lands, or at least in Austria, Moravia, Styria and Bohemia, "a public locus" was to be established in all suitable cities and towns, intelligence points which were to be under the direction of a "directorio or superior intelligence house" at the Imperial Court. In these institutions, anyone might register and have his needs entered into a "protocol or Journal". In addition to the scribes necessary for this, some "intelligence clerks" would have to be employed, "who could be used for sending out, inquiries, negotiations and the like". 21

There were five different media-so-called intelligentien - for the publication of demands submitted to an intelligenth-Hauß: 1. The "Journal or Protocol" kept at the intelligence house, which interested parties would be able to

18 W.v. Schröder, Fürstliche Schatz- und Rent-Cammer (Leipzig, 1686), pp. 495-8: "allwo ein jeder ohne Reisen oder, Botenschicken in einer Viertelstund alles wissen könne, was in allen diesen Ländern zu verkauffen, und wo ein jedes zu finden sey; gute Ordnung im Handel; die zeit mit lauffen zu verlieren".

19 Schröder, Fürstliche Schatz- und Rent-Cammer, pp. 503-4: "Das Bothen schicken, item das in commission geben ... macht eine sache theuer; fremde Ankömling; mehr Schaden und Unheil als Nutzen".

20 Schröder, Fürstliche Schatz-und Rent-Cammer, pp. 155-8.

21 Schröder, Fürstliche Schatz- und Rent-Cammer, pp. 505-7: "intelligentz-Bediente, welche man zum Ausschicken, nachfragen, unterhandeln und dergleichen gebrauchen". 
inspect; 2. a 'board' outside the intelligence house; 3. a public proclamation "per proclamationem vocalem"; 4 . communications to other intelligence houses; 5. "per charta publicam", a weekly intelligence paper, which would advertise the information, services or goods offered or demanded in the whole of the country, and which was to be published weekly or bi-weekly, "just like the newspapers". Schröder listed different examples for its use: a master looking for a trumpeter would be able to notify the intelligence house of his need. Likewise, a bargeman departing for Bratislava (Pressburg) might publish the fact in order to recruit passengers, or a bargeman arriving whose cargo consisted of lard might have it proclaimed and find buyers. And whenever the army stood in need of oats, wine or horseshoes, it would be able to place this information in the intelligence paper. ${ }^{22}$

The proposed Intelligenzwerk thus was to use a mix of media in order to achieve its brokering function. No private person would be excluded from creating such an institution; it was, however, to be placed under public supervision like the postal services in order to prevent fraud. ${ }^{23}$ Schröder's conclusion: the Intelligenzwerk was "simply and ill made, but full of advantages"; it would facilitate doings and dealings, alleviate poverty and, last but not least, increase His Majesty's income. ${ }^{24}$ His proposal of a communication network transcending borders was not put into practice; later authors took it up and some future implementations of intelligence offices would be based on it. ${ }^{25}$

\section{Leibniz's Plans}

Gottfried Wilhelm Leibniz was one of the seventeenth-century scholars whose imagination was captivated by the idea of intelligence offices. ${ }^{26} \mathrm{He}$ knew the lectures published by the Paris Bureau d'adresse and the London offices of intelligence and over several decades, he proposed plans for similar institutions, which sometimes tended in the direction of a comprehensive agency of education and brokerage, sometimes more towards an intelligence office mostly

22 Schröder, Fürstliche Schatz- und Rent-Cammer, pp. 508-11.

23 Schröder, Fürstliche Schatz- und Rent-Cammer, pp. 507-8.

24 Schröder, Fürstliche Schatz- und Rent-Cammer, p. 511: "einfältig und schlecht beschaffen, aber so voller nutzbarkeit".

25 E.g. H. Bode, Fürstliche Macht-Kunst oder unerschöpffliche Gold-Grube, Wordurch ein Fürst sich kan mächtig und seine Unterthanen reich machen (Vienna, 1703), pp. 130-3; J.B.v. Rohr, Einleitung zur Staats-Klugheit, Oder: Vorstellung Wie Christliche und weise Regenten zur Beförderung ihrer eigenen und ihres Landes Glückseeligkeit Ihre Unterthanen Zu beherrschen pflegen (Leipzig, 1718), pp. 935-6; Astride Blome, 'Das Intelligenzwesen in Hamburg und Altona', in Doering-Manteuffel et al., Pressewesen der Aufklärung, pp. 183-207, at 188. 
concentrated on commercial purposes with a focus on the services of a sales and employment agency. ${ }^{27}$

Thus, in his Drôle de pensée of 1675, Leibniz sketched an educational and recreational institution that went beyond Renaudot and was to be, amongst others, a "bureau general d'adresse pour tous les inventeurs", a general intelligence office for inventors:

All those who had an invention or an ingenious idea to offer would be welcome; here they would find the occasion to earn their living, to publicise their invention, and profit from it ... Soon, there would be a theatre of all imaginable things: a menagerie, a garden of medicinal herbs, a laboratory, an anatomical theatre, a cabinet of curiosities. All those eager for knowledge would be able to turn to it ... And academies, colleges, tennis courts and more would be incorporated; concerts and picture galleries, colloquies and conferences. ${ }^{28}$

In connection with his proposed journal Semestria Literaria - it was to be published in two to three volumes coinciding with the Frankfurt Fair, and contain inventions and new ideas as well as reports of recently published books, with an 'excerpt of the quintessence'-Leibniz developed plans for a general information office for writers, which was to support scholars who wanted to take up useful works, but had no access to a publisher. ${ }^{29}$

The draft on the Errichtung eines Notiz-Amtes (establishment of an office of notices) that may have been written in the years $1712-13$ was elaborately developed; this time, the institution was to fund the Imperial Society of Science. Through it, "people who are in need of each other would be able to become

27 Gottfried W. Leibniz, 'Bedenken von Aufrichtung einer Akademie oder Societät' (1671?), in Leibniz, Sämtliche Schriften und Briefe, series 4, political writings, vol. 1 (Berlin: Akademie Verlag, 1983), pp. 543-52, at 548; Gottfried W. Leibniz, letters to Gilles Filleau des Billettes, Hannover 3 and 13 July 1692 and 8 December 1692, in Leibniz, Sämtliche Schriften und Briefe, series 1, general political and historical correspondence, vol. 8 (Berlin: Akademie Verlag, 1970), pp. 332-4, 567-70, at 333 and 568.

28 Gottfried W. Leibniz, 'Drôle de pensée' [September 1675], in Leibniz, Sämtliche Schriften series 4, political writings, 1: 562-8, at 565; German translation in Horst Bredekamp, Die Fenster der Monade. Gottfried Wilhelm Leibniz' Theater der Natur und Kunst (Berlin: Akademie Verlag, 2004), pp. 237-46, at 42; see 43-80 for an analysis of the Leibnizian Gedankenscherz.

29 Gottfried W. Leibniz, 'Semestria Literaria' [autumn 1679], in Leibniz, Sämtliche Schriften series 4, political writings, 3: 775-86, at 782: Auszug des kerns. 
aware of each other" ${ }^{30}$ Until now, the meeting of buyers and sellers, workers and publishers, carters and bargemen with their cargos etc. depended solely on chance, and not a few had "fallen prey to debt, harm and disaster" because no-one knew of them, while others had "risen up", because they had been lucky enough to find a patron; by means of the Notiz-Amt, "chance" would "turn into certitude". ${ }^{31}$ The society Leibniz thus wanted to create with this institution was one in which exchange processes would not proceed in a chaotic but in a regulated way, an argument which Renaudot had already used to justify his Bureau d'adresse. Leibniz did not, however, aim to completely exclude chance, but to build it into the process of information brokerage in a planned way: when consulting the Notiz-Amt, "people often find something they do not look for, and often they have occasion to find and ask for something which they would not otherwise have thought of". ${ }^{32}$ Serendipity is the art of finding something one has not initially been looking for; Leibniz was familiar with this phenomenon and worked it into his conception.

Another benefit of the information office Leibniz cited was that people would become better linked through it: as opposed to the countryside, where they lived "far spread out from each other", the "main advantage" of cities was that people lived closer together and were "more easily able to find each other". The Notizamt would add to this trend, even make it complete: ${ }^{33}$

... people will be even more united and so to say concentrated, so that one morally approaches the other and comes into virtual contact with him, even if they are not physically [brought] together and do not live in the one house; they will approach each other, get to know one another and be more strongly bound to each other. ${ }^{34}$

30 Gottfried W. Leibniz, 'Errichtung eines Notiz-Amtes/Création d'un bureau d'adresse', in Leibniz, Oeuvres, vol. 7: Leibniz et les Académies. Leibniz et Pierre le Grand, ed. Alexandre. Foucher de Carail (Paris: F. Didot, 1875), pp. 358-66, at 358: "leute, die einander von nöthen haben, von einander kundschafft bekommen können".

31 Leibniz, 'Errichtung eines Notiz-Amtes', pp. 359-6o: "in schulden, schaden und verderben gerathen; auß einem zufälligen etwas gewißes".

32 Leibniz, 'Errichtung eines Notiz-Amtes', p. 359: “findet offt einer was er suchet, bekomt auch offt gelegenheit etwas zu suchen und zu verlangen, darauff er sonst nicht gedacht hätte".

33 Leibniz, 'Errichtung eines Notiz-Amtes', p. 366: "weit von einander zerstreuet; hauptvortheil".

34 Leibniz, 'Errichtung eines Notiz-Amtes', p. 366: "[D]ie menschen werden noch mehr vereiniget und so zu sagen concentriret, also daß sich einer dem andern moraliter nähert und gleichsam ad contactum komt, da sie doch physice nicht beysammen und nicht in einem hause wohnen; they would sich einander nähern, sich kennen lernen und fester mit einander verknüpfet werden". 
Leibniz's conclusion: "police and order, doings and dealings, trades and manufactures, studies and arts" would therefore be "exceedingly stimulated". 35

In a similar manner to his predecessor Wilhelm von Schröder, Leibniz wanted to cover the whole of the German Empire, and also Italy, in a network of Notizämter; they were not only to be established in cities but also in towns. ${ }^{36}$ A number of services were to be provided, which went over and above the usual brokering services-and which, incidentally, were also open to anonymous use. ${ }^{37}$ The Notiz-Amt was to serve as a store for valuables, as a venue for auctions and lotteries, it was to publicly document contracts and administer pious endowments; in addition, it might be joined to a "work or poor house or orphanage" as well as an office of weights and measures. Finally, it might also be used to supervise the Jews - Leibniz seizes on an ancient prejudice herewhose "whole sustenance in general" consisted of "felonies". 38 This enlistment by the authorities was even emphasised by Leibniz's suggestion of using the Notiz-Amt, according to the Venetian example, as a receiving office for anonymous reports. Here, Leibniz felt it necessary to stress that this function should not be abused. ${ }^{39}$

Finally, in Leibniz's vision, the Notiz-Amt would also publish a printed medium, namely a weekly or monthly "diarium of useful matters occurring", providing information to those living in the country. It was to publicise those matters which would otherwise be posted on placards, and promote recently published books, medicines and inventions, curiosities and sights. The advantage of such a diarium connected to the registry of the Notiz-Amt would be that "such often useful matters (might) be preserved for the information of posterity"; the same applied to decrees by the authorities, which were to be printed in the diarium. ${ }^{40}$ Even more than the French and English models, the information offices conceived by Leibniz assume some of the function of police institutions: they were not only to facilitate brokerage, but also to take on surveillance tasks.

35 Leibniz, 'Errichtung eines Notiz-Amtes', p. 366: "polizey und ordnung, handel und wandel, commercien und manufacturen, studien und künste überauß befördert werden".

36 Leibniz, 'Errichtung eines Notiz-Amtes', p. 363.

37 Leibniz, 'Errichtung eines Notiz-Amtes', p. 360.

38 Leibniz, 'Errichtung eines Notiz-Amtes', pp. 364-5: "ganze nahrung insgemein in schacherey".

39 Leibniz, 'Errichtung eines Notiz-Amtes', pp. 360-1.

40 Leibniz, 'Errichtung eines Notiz-Amtes', pp. 361-2: “diarium der dienlichen fürgefallenen dinge; solche offt nüzliche sachen ... der nachwelt zur nachricht in gedächtniß erhalten werden". 


\section{Frag- und Kundschaftsämter in the Habsburg Monarchy in the Eighteenth Century}

\section{The Vienna Frag- und Kundschaftsamt}

In 1707, an information office called Fragamt (inquiries office) was founded in Vienna; originally, it was closely connected to a pawn office (Versatzamt) established at the same time, and was to finance the Great Poorhouse, which had been in existence since $1693 .{ }^{41}$ The Versatz- und Fragamt founding patent dates from 14 March 1707 and defined the activities of the Fragamt as those of a sales agency; there was no mention of additional brokering activities or the publication of an advertising paper. ${ }^{42}$ Possibly the latter was dropped out of respect for the Wienerisches Diarium, a printed newspaper published since 1703, which continues to this day under the name Wiener Zeitung (since 1781); there is, however, no clear evidence for this assumption.

More extensive activities of the Fragamt are documented only from 1721; at this time, the Fragamt was installed in a separate venue from the Versatzamt and it began its cooperation with the Wienerisches Diarium by publishing the

41 For literature on the Vienna Fragamt, see e.g. [Anonymous], 'Zur Geschichte des Wiener Fragamtes', Wiener Communal-Kalender und städtisches Jahrbuch, 31 (1893), pp. 419-26; Hans Hülber, Arbeitsnachweise, Arbeitsvermittlung und Arbeitsmarktgeschehen in Österreich in vorindustrieller Zeit unter besonderer Berücksichtigung Wiens. Eine sozial-und wirtschaftsgeschichtliche Studie (Vienna: Verien fur Geschichte der Stadt Wien, 1975), pp. 22-30; Wolfgang Duchkowitsch, Absolutismus und Zeitung. Die Strategie der absolutistischen Kommunikationspolitik und ihre Wirkung auf die Wiener Zeitung 1621-1757, $\mathrm{PhD}$ thesis (University of Vienna, 1978), pp. 311-57; Bobrowsky, Wiener Intelligenzwesen; Tantner, Adressbüros, pp. 95-118; and Tantner, 'Das Wiener Frag- und Kundschaftsamt. Informationsvermittlung im Wien der Frühen Neuzeit', Wiener Geschichtsblätter, 66.4 (2011), pp. 313-42. <phaidra.univie.ac.at/o:105527> [8/1/15]. For accounts of the foundation of the pawn office and Fragamt, cf. especially Karl Weiss, Geschichte der öffentlichen Anstalten, Fonde und Stiftungen für die Armenversorgung in Wien (Vienna: Wilhelm Braumüller, 1867), p. 123; Albert Starzer, Das k.k. Versatzamt in Wien von 1707 bis 1900 (Vienna: Direction des k.k. Versatzamtes 1901), pp. 9-10; Bobrowsky, Intelligenzwesen, pp. 29-30; on the Great Poorhouse, see also the chronicle in the Niederösterreichische Landesarchiv: Niederösterreichisches Landesarchiv, St. Pölten (NÖLA), NÖ Regierung, Diverse Protokollbücher-Protokolle in Großen Armenhaus-Sachen, VersatzamtsSachen 1626-1808, Nr. 64/8: Gedenkprotokoll über Merkwürdigkeiten im Großen Armenhaus, undated.

Codex Austriacus III: Supplementum Codicis Austriaci (Leipzig, 1748), pp. 531-5, citations at 534-5; cf. also Wiener Stadt- und Landesarchiv (WStLA), Patente, series 1, no. 1011, 14 March 1707. 
so-called 'Negotienlisten' there, which consisted of registry excerpts of the entries listed in the Fragamt protocol. ${ }^{43}$ Most of these notices concerned the sale of movables and real estate and the loaning of money; the Fragamt sometimes also served as an exhibition venue for goods on sale. A novelty was that the Fragamt offered a placement service; this service was mainly directed at servants, and the Fragamt attempted to take over police functions by prompting individuals looking for a position as a servant to submit details on their age, place of birth, parentage, financial circumstances and skills, as well as to provide certificates of conduct and letters of recommendation. ${ }^{44}$

The protocol at the Fragamt and the 'Kundschaftsblätter' (information sheets), which in part were a supplement to the Wiener Diarium, but which could also sometimes be bought separately for the price of one kreutzer were not the only medium the Fragamt used for the registration and publication of submitted demands: there was also a posting board on display in front of the office, on which 'all submitted requests and inquiries (were) posted daily, omitting names'.45 In addition to the Kundschaftsblatt, lists were printed, which were available on demand at the office, containing lodgings for rent and available servants. ${ }^{46}$

In the same year of 1721, the printer Johann Peter van Ghelen (1673-1754) took over the Diarium, so the printing of the 'Negotienlisten' also devolved on

43 Codex Austriacus Iv: Supplementum Codicis Austriaci, Pars II (Vienna, 1752), pp. 7-8. The following prints kept at the WStLA, Hauptarchiv, Akten, series B, no. 1117/1710 served further publication: Richt-Schnur/So bey Ihro Römisch-Kayserlich- und KöniglichCatholischen Majestät Frag-Ambt/Die Universal-Kundschafft/ja fast eines jedwedern Negotii einzuführen und zu remonstriren zu jedermanns Nutzen und Beförderung entspringet, n.d. (1721); Auß dem Der Röm. Kays. Und Königl. Cath. Majestät Neu-auffgerichten Frag- und Kundschaffts-Ambt Wird hiemit Jedermänniglichen zu wissen/und kund gethan, n.d. (1721); Kurtzer Innhalt und Unterrichtung Auß dem neu aufgerichteten UniversalKundschafft- und schrifftl. Niederlags-Ambt/worinnen auß folgenden absonderlich allhier inserirten Puncten/zuersehen/was Massen zu Nutzen und Frommen des gemeinen Wesen/ die sonsten zu machen habende schwere Unkosten/grosse Speesen und langwierige ZeitTrainirung aufgehoben; hingegen die erspießliche Leichtigkeit des Handel- und Wandels allen Hoch- und Niedern Stands-Persohnen zu schleunigerer Beförderung hergestellet werden könne, n.d. (1725). The first of the Negotienlisten was published on 4 June 1721: Wienerisches Diarium (WD), no. 1862, 4-6 June 1721; see Bobrowsky, Intelligenzwesen, pp. 38-9.

$44 \quad W D$, no. 2, 7 January 1722.

$45 W D$, no. 31, 15 April 1724; WD, no. 85, 23 October 1723; WD, no. 31, 15 April 1724: alle eingehende Begehren und Anfragen mit verschwiegenen Namen ... täglich angeheftet.

$46 \quad W D$, no. 31,15 April 1724. 
him, which later appeared separately and were called Kundschaftsblatt. ${ }^{47}$ In April 1728 at the latest, the Fragamt moved to the premises of the Wienerisches Diarium, Ghelen launched a regular advertisement campaign for the Kundschaftsblatt and, besides sales advertisements for movables and real estate, free positions and travel opportunities, also published arrest warrants, missing persons reports and announcements of recently published books; at times there were reports on scientific phenomena or spectacular crimes; until the 1770s, it also included announcements of religious services. ${ }^{48}$

47 Anton Mayer, Wiens Buchdrucker-Geschichte 1482-1882, 2 vols. (Vienna: W. Frick, 1887), 2: 14-15, note 58; E.V. Zenker, 'Die Geschichte der Wiener Zeitung in ihrem Verhältnisse zur Staatsverwaltung auf Grund archivalischer Forschungen dargestellt', Wiener Zeitung, supplement (Jubiläums-Festnummer der kaiserlichen Wiener Zeitung 8 August 17031903), 8 August 1903 <anno.onb.ac.at/cgi-content/anno-plus?aid=wzj> [8/1/15], pp. 1-12, at 2-3; Duchkowitsch, Absolutismus, pp. 265-88; Österreichisches Staatsarchiv (ÖStA), Haus-, Hof- und Staatsarchiv (HHStA), Reichshofrat (RHR), Gratialia et Feudalia (Grat. Feud.), Impressorien (Impr.), cart. 63, at bundle I, no. 18: Resolution of Karl vi to Johann Baptist Schönwetter, 22 October 1721. On Ghelen see e.g. Peter R. Frank and Johannes Frimmel, eds., Buchwesen in Wien 1750-1850. Kommentiertes Verzeichnis der Buchdrucker, Buchhändler und Verleger (Wiesbaden: Otto Harassowitz Verlag. 2008), pp. 77-8. $W D$, no. 27, 3 April 1728. The title of this paper was to undergo slight changes over the following decades of its existence, its original title was Post-tägliche Frag und AnzeigungsNachrichten/des Kaiserl. Frag- und Kundschafts-Amt in Wien (PFAN), from 3. 11. 173, the title was Wienerische Post-tägliche Anzeigung und Nachricht von allerhand Licitationen: Citationen: Besitzungen deren Grund-büchern: Convocationen und Tag-satzungen wegen Verlassenschaften und Anforderungen. verschiedene Notificationen: item von gestohlenen/ verlornen/und gefundenen Sachen: Andachten in und vor der Stadt: von gelehrten Leuten und Sachen/neu auskommenden Büchern/Naturalien/Maschinen/und dergleichen Erfindungen: wie auch besonderen Begebenheiten und seltsamen Zufällen. Und letztlichen die Nachrichtliche Anzeigungen des Kaiserl. Frag-und Kundschaft-Amts in Wien/von allerhand inner und ausserhalb der Stadt täglich zu kauffen/und verkauffen oder zu vertauschen/zu verleihen und lehnen vorkommenden/Sachen/sodann Personen/welche lehnen und ausleihen wollen/Bedienungen oder Arbeit suchen oder zu vergeben haben/auch von Fuhr-leuten/ Schif-leuten/Reisenden/etc. (WPAN); later, there were some smaller changes to the title: from 1747 until at least 1765 the paper was called Post-tägliche Anzeigung/und Nachricht aus dem Kaiserl. Frag- und Kundschaft-Amt in Wien (PAN), from at the latest 1773 Posttägliche Anzeige aus dem k.k. Frag- und Kundschaftsamte in Wien (PA).

For 1728 and $1730-54$ and $1763^{-65}, 1779,1794-1805,1807$ and $1809-13$, volumes bound per year are in the Wienbibliothek at the Rathaus (sig F 19.111, supplement volume); in addition, the Austrian National Library has the years $177^{-}-75,1780-83$ and 1785-88 (signature 1,005.524-D, supplement) and 1794-99 (signature 393.052-D.Alt, supplement); cf. Helmut W. Lang (ed.), Österreichische Retrospektive Bibliographie (о в BI). Reihe 3: Österreichische Zeitschriften 1704-1945, vol. 1 (Munich:Saur 2006), pp. 414-16, 437-8 (no. 3.1: 686-9, 731). 
Comparatively rarely, the Fragamt served as a vending venue for some of the advertised goods or as a collection point for lost articles: in 1731, lutes, Neapolitan soap, and a tincture against warts were on sale there, and a lost silver stamp awaited collection. ${ }^{49}$ In 1762 , the Fragamt, the privilege of which was now in the possession of Ghelen's successors, was jeopardised by the printer Johann Thomas Trattner. He planned to establish a network of Intelligence Offices spanning the whole of the Habsburg monarchy, with similar functions to the Fragamt; in addition, he wanted to publish a so-called Intelligenzblatt (intelligence paper) twice a week, which was to publish mainly commercial news. Trattner's idea finally failed because the Fragamt privilege was ruled to be untouchable. ${ }^{50}$ Over the following decades, the Fragamt continued its activities without causing any sensation; nor did the Josephine reforms bring many innovations; plans to merge the Fragamt with the Viennese city post, the Kleine Post, which had been nationalised in 1785 were not pursued in the end. ${ }^{51}$ At the beginning of the nineteenth century, during the years 1801 to 1814, the Fragamt slowly ceased to exist; the last edition of the Kundschaftsblatt was probably published on 30 December 1813; its contents formed part of the reformed Wiener Zeitung after that.

How significant was the Fragamt? Voices conceding it little importance predominate in answers to this question. Thus, the Kundschaftsblatt published by the Fragamt was little appreciated by the authorities, as its readership was too limited and brought few benefits..$^{52}$ The assessment of the work placements achieved by the Fragamt was similarly negative: in 1764 , the Chancellery mentioned in a lecture that the institution had "not achieved its purpose" in this area. $^{53}$

49 PFAN, no. 36, 5 May 1731; PFAN, no. 47, 13 June 1731.

5o ÖStA, Finanz- und Hofkammerarchiv (FHKA), Neue Hofkammer (NHK), Kommerz Oberund Niederösterreich, cart 85 (formerly red number 86), fasc. 35, fos. 4-9, 32-108, 143; cf. also WStLA, Alte Registratur, A2, 107/1763 IV 11 and Moravský zemský archiv, Brno (MZA), B1 Gubernium, cart. 51, B6/55, fos. 908-10.

51 ÖStA, FHKA, NHK, Österreichisches Kamerale, Akten, red number 412, fasc. 9/11, 32 ex March 1785, fos. 168-179, at 170v, 179r: presentation of Hofkanzlei, Hofkammer and Bankodeputation, 20 February 1785; cf. Eduard Effenberger, Aus alten Postakten. Quellen zur Geschichte der österreichischen Post, ihrer Einrichtungen und Entwicklung (Vienna: Verlag d. "Zeitschrift für Post u. Telegraphie" Spies 1918), p. 257.

$5^{2}$ ÖStA, FHKA, Kommerz Ober- und Niederösterreich, cart 85 (formerly red number 86), fasc. 35: Vienna Council to Lower Austrian government, pr. 12 April 1763, fos. 55, 78-82, draft at WSTLA, Alte Registratur, A2, 107/1763 IV 11, exp. 11 April 1763.

53 Die Arbeitsvermittlung in Österreich. Edited by the Department of Statistics at the I. R. Handelsministerium (Vienna, 1898), p. 30, note 1: Endzweck nicht erreicht; this presentation, dated 15 December 1764 , does not seem to exist any more. 
The Fragamt seems to have played a certain role in brokering real estate. The number of available lodgings was so great that there was insufficient space in the Kundschaftsblatt: In 1780, the Wienerisches Diarium announced to its readership that on the occasion of the customary change of lodgings at the coming Candlemas feast, the Fragamt would offer a special protocol for available lodgings. The fee for registering an empty apartment was 14 kreutzer, with lodging seekers paying seven kreutzer for information. ${ }^{54}$ Nicolai, a visitor to Vienna, also mentions this service in his travel report and calls it 'a very useful institution, 55

The question remains why this institution, given that it had so little importance and was relevant at most in procuring or renting out lodgings, was able to exist for decades. One possible, rather open-hearted explanation was given by Johann Peter van Ghelen's successor, Johann Leopold van Ghelen, as early as 1758: if someone else were to take over the Kundschaftsblatt, they might enhance it with editorial content and thus compromise the Diarium's privilege, which would lead to "manifold vexations". Ghelen was anxious to avoid possible legal disputes, and he was prepared to "buy his peace" for the price of a financial loss generated by the Kundschaftsblatt. ${ }^{56}$ Ghelen also wanted to secure the monopoly of the Wiener Diarum as the only German newspaper in Vienna, and to eliminate potential competition from the outset, a scheme that became obsolete with the reorganization of the Viennese press around 1810: as in other cities, the information office dissolved into the advertisement department of the newspaper it was connected to.

\section{The Prague and Brno Fragämter}

After its creation, the Vienna Fragamt became a matter of interest in other lands of the Monarchy, too. Nonetheless, it took until the mid eighteenth century to establish Fragämter in Prague and Brno. ${ }^{57}$ In Prague, the establishment

$54 W D$, no. 4, 12 January 1780.

55 F. Nicolai, Beschreibung einer Reise durch Deutschland und die Schweiz, im Jahre 1781 (Berlin/Stettin, 1783, reprint Hildesheim et al., 1994) (Gesammelte Werke; 16, ed. Bernard Fabian and Marie-Luise Spieckermann), vol. 3, p. 270: sehr nützliche Anstalt.

56 NÖLA, NÖ Regierung, Maria Theresianische Verwaltung, Hofresolutionen in publicis, cart 155 (June 1774): Johann Leopold Edler von Ghelen to Lower Austrian Repräsentation and Kammer, pr. 6 November 1758: vielfältige Verdrüßlichkeiten; cf also the account in Duchkowitsch, Absolutismus, pp. 348-57.

57 For a more detailed account, see Tantner, Adressbüros, pp. 118-39 and Anton Tantner, 'Die Frag- und Kundschaftsämter in Prag und Brünn. Informationsvermittlung im frühneuzeitlichen Böhmen und Mähren', Folia Historica Bohemica, 26.2 (2011), pp. 479-506. $<$ phaidra.univie.ac.at/o:105529> [8/1/15]. For a general history of the newspaper business 
of a Versatz- und Fragamt was granted in 1747; it was to fund the penitentiary and workhouse, and largely followed the Viennese example of 1707.58 The Prague Fragamt started its operations in 1752; initially it was directed by the later Bohemian Kommerzieninspektor and Lower Austrian government councillor Joseph Ferdinand Bock (von Pollach) and published a weekly Kundschaftsblatt with a print run of 350 copies, which at first was titled In [sic] Königreich Böheim. Wochentliche Frags- und Anzeigs-Nachrichten. ${ }^{59}$ The sale of this Kundschaftsblatt was the main source of income for the Fragamt; proceeds from registration fees for the Fragamt protocol were comparatively unimportant. At least during the early years, the Prague population seems to have been little disposed to use the Fragamt; it was mostly used for looking for work.

Later, the Prague Fragamt changed its ownership several times: in April 1756, Bock ceded its direction to the Prussian native Carl Ernst von der Groeben, who, as early as September 1756, transferred its management to Anton Hillgartner, who was the manufactures commissioner for the Kaurzim district. ${ }^{60}$ As its debts with the printer Ignaz Pruscha continued to increase, it was

in the Bohemian lands, see Zdeněk Šimeček,: Počátky novinového zpravodajství a novin v českých zemích (do devadesátých let 18. stoletî) (Brno: Matice moravská, 2011).

58 Národní Archiv, Prague (NA), Patenty, 1747 záři 4: Versatzamtspatent, 4 September 1747; patent draft in NA, Staré české místodržitelstvi (sČM) 1747/VI/ch/57, cart 651; NA, SČM 1747 $\mathrm{X}$ ch KK 1182, cart 655: Bohemian government to Kreisämter, 3 October 1747; for general information on the Prague Versatzamt, see Jindřich Frohmann, O pražské zastavárně, době a lidech kolem ní. (Dějiny státního zástavního a půjčovního úřadu v Praze). Význam vývoje hospodářského a vývoje sociálnich tř́d v našem národním obrození (Prague: Vydavatelské, nakladatelské a tiskařské družstvo Obnova, 1947).

59 NA, Česke Gubernium, Publicum (ČG-Publ.), 1748-1755, O 3, cart 130: memorandum, 19 January 1763; NA, ČG-Publ. 1748-1755, O 3, cart 130: 'Berechnung Über den a 1ma Aprilis Anno 1753 intuito des Neuerrichteten Frag-Ambts für die gewöhnl: Wochenblätter a Nro 13 bis ad Nro 52 inclusive dann an Einschreibgebührnüssen, Eingekommenen Geld Empfang, und respective Ausgaab', n.d. Copies of this Kundschaftsblatt, which during the period 1755 to 1771 mostly bore the title In/Im Königreich Böheim (ІКВ), originally were stored at the Knihovna Novinářského studijního ústavu v Praze (currently: Knihovna Fakulty sociálních věd uK, Prag). According to information from Dagmar Kulhánková (email 15/1/08), the originals were restituted to the Lobkowitz family in Krimnice; at the Knihovna Fakulty sociálních věd UK, there are microfiches of these originals for the (partly incomplete) volumes 1754-55 and 1757-69. On Bock: Petr Voit, Encyklopedie Knihy. Starši knihtisk a př́buzné obory mezi polovinou 15. a počátkem 19. století (Prague: LIBRI, 2006), pp. 126-7, sv "Bock von Pollach Josef Ferdinand".

6o NA, ČG-Publ. 1756-1763, N 2 cart 215: Cession Bock to Groeben, 22 April 1756; Groeben to Bohemian Repräsentation und Kammer, ps. 26 April 1756; NA, ČG-Publ. 1756-63, N 2 cart 215: Bohemian Repräsentation und Kammer to Otto Ludwig von Loscani, 27 September 1756. 
only logical that Hillgartner ceded it to him as of 19 September $1757 \cdot{ }^{61}$ Pruscha was also unable to generate much income from the Fragamt, for which he had to pay an annual lease of 50 guilders to the workhouse. During the early years of his administration, the Kundschaftsblatt had as few as 90 subscribers. ${ }^{62}$ After his death in 1762, the Fragamt fell to his widow, Johanna Pruschin, and under her direction it continued to be a money-losing proposition. ${ }^{63}$ In 1774, she left the lease to her son Vincenz Victorin Pruscha. ${ }^{64}$ From 1777, he developed the Kundschaftsblatt into a full-blown political newspaper, which is also evident in several changes to its title. The Prager Intelligenzblatt (Prague intelligence paper, 1777) in 1779 became the Prager (außerlesene und) interessante Nachrichten (Prague select and interesting news) and finally the Prager Staatsund gelehrte Nachrichten (Prague state and learned news, 1789-95). ${ }^{65}$

At the time of the Pruscha family's direction, the Prague Fragamt was mainly frequented for work placements, but also for real estate brokerage. For the latter, the supply of rental apartments was so considerable that it was impossible to describe all of them in detail in the Kundschaftsblatt, and interested parties were asked to refer to the Fragamt. ${ }^{66}$ During the last years of Pruscha's

61 NA, ČG-Publ. 1756-63, N 2 cart 215: Cession Hillgarten to Pruscha, 19 September 1757.

62 NA, ČG-Publ. 1756-63, N 3 cart 215: Pruscha, Ignaz: 'Vorschlag durch was Mittel ... das ... Prager Frag- und Kundschaft-Amt ... empor gebracht werden könnte.', n.d. (received 11 April 1761).

63 Voit, Encyklopedie Knihy, 721-2, sv 'Pruša Ignác František'.

64 NA, ČG-Publ. 1764-73, N 2/1 (folder Poptavkový úřad), carton 445: 'Gewißenhaftes und ausführliches Verzeichniß aller und jeder bey dem Prager Frag- und Kundschaftsamte seyenden Einnahmen und Ausgaben', 12 September 1770; on the journal edited by Johanna Pruschin in 1770-71, Die Sichtbare, see H. Meise, 'Morality, fiction and manners in the moral weeklies in Prague', in The Enlightenment in Bohemia. Religion, Morality and Multiculturalism (Studies on Voltaire and the Eighteenth Century, 7), ed. Ivo Cerman, Rita Krueger and Susan Reynolds (Oxford: Voltaire Foundation, 2011), pp. 89-110.

65 Title 1777: Prager Intelligenzblatt aus dem k.k. privilegirten Frag- und Kundschaftsamte; 1778: Neu verbessertes Prager Real Conversations Intelligenzblatt aus dem k.k. privilegirten Frag- und Kundschaftsamte; 1779-1780: Prager außerlesene und interessante Nachrichten, nebst der eigentlichen Intelligenz, aus dem k.k. privil. Frag-und Kundschaftsamte; 1781-1788: Prager interessante Nachrichten, aus dem k.k. priv. Frag-und Kundschaftsamte (PIN); 17891795: Prager Staats- und gelehrte Nachrichten, nebst dem eigentlichen Intelligenzblatte aus dem k.k. Frag- u. Kundschaftsamte (PSGN); 1796-1811: Kaiserlich Königlich priv. Prager Intelligenz-Blatt (PI). Surviving volumes can be found amongst others at the Strahovská knihovna, signatures AT XVIII 1-8 (1764-1772, 1779, 1780, 1787), A V XVIII 24-5 (1786, 1788); A V XVIII 12-21 (1790-1795) and at the Národní knihovna České republiky (NKP), Signaturen $5^{2}$ D 85 (1777, 1778, 1796-1803, 1805-1811), 65 D 397 (1781-1795).

$P I N, 3$ February 1781, no 5, similarly PSGN 9 August 1789, no 32, supplement. 
direction, the Fragamt got competition from an information office founded by the publisher Johann Nepomuk Ferdinand Schönfeld (1750-1821). ${ }^{67} \mathrm{He}$ was the editor of the von Schönfeldsche k.k. Prager Oberpostamtszeitung, and in 1789 at the latest, he opened his own shop for goods of all kinds, which he complemented with an Addre $\beta$ - und Zeitungskomtoir. ${ }^{68}$ It offered clerical services and also aimed to provide information services. ${ }^{69}$

Thus, from the beginning of the 179os, there were two information offices in Prague, i.e. the Fragamt owned by Vincenz Victorin Pruscha, and Johann Ferdinand Schönfeld's Adresscomptoir: however, this redundancy existed for a short time only, as Pruscha died on 9 October 1793 and his successors were no longer willing to continue the Fragamt..$^{70}$ The privilege for the Fragamt as well as the associated advertising paper were subsequently sold at auction in January 1794, and Schönfeld himself made the successful bid. ${ }^{71}$ After Johann Ferdinand Schönfeld's death - he died in Vienna on 15 October 1821, where he had lived since the 1790 - - his heirs did not continue the newspaper and Fragamt for long, but sold both to the printing business Gottlieb Haase (Söhne) in $1824 .{ }^{72}$ Until the 1830 s, the Fragamt continued to exist as an appendage to the advertisement paper of the Prague newspaper. ${ }^{73}$

In the Moravian capital Brno, the establishment of a Fragamt was initiated in 1751 ; there, it was established in connection with the Mährische Lehenbank

67 On Schönfeld cf. Michael Wögerbauer, 'Johann Nepomuk Ferdinand Schönfeld. Ein Buchdrucker und Sammler im josephinischen Zeitalter', in PORTHEIM. Sammeln \& verzetteln. Die Bibliothek und der Zettelkatalog des Sammlers Max von Portheim in der Wienbibliothek, ed Reinhard Buchberger, Gerhard Renner and Isabella Wasner-Peter (Vienna: Sonerzahl Verlagsges, 2007), pp. 180-201; Voit, Encyklopedie Knihy, pp. 795-6, sv 'Schönfeld z Schönfeldu Jan Nepomuk Ferdinand'; Margarethe Egger, Die Familie Schönfeld und ihre kulturelle Bedeutung für Wien, PhD thesis (University of Vienna, 1951). For general information on literature, printing and the book trade in Prague, see Michael Wögerbauer, Die Ausdifferenzierung des Sozialsystems Literatur in Prag von 1760 bis 1820, $\mathrm{PhD}$ thesis (University of Vienna, 2006).

68 Prager Oberpostamtszeitung (POPAZ), supplement, 1 piece, 2 January 1790, 1.

$69 \quad P O P A Z$, supplement, 1 piece, 1 January 1791, 1.

$70 \quad P S G N, 12$ October 1793, no. 41, supplement.

71 Przedak, Intelligenzblatt, 75-82; NA, ČG-Publ. 1796-1805, 102/24-163, cart 4052: Contract Schönfeld with Kammerprokuratur, 31 March 1794.

72 Egger, Schönfeld, p. 74; Wögerbauer, Schönfeld, pp. 188, 192; Przedak, Intelligenzblatt, p. 123.

73 Sebastian W. Schiessler, Neues Gemälde der königlichen Hauptstadt Prag und ihrer Umgebungen. Ein Taschenbuch für Fremde und Einheimische (Prague: Enders, 1834), pp. 152-3; cf. also A.A. Glückselig (pseud. Gustav Thormond Legis), Topographischer Grundriss von Prag und dessen Umgebungen (Prague, 'Gottlieb Hasse Sohne', 1835), pp. 206, 209. 
(Moravian loans bank) founded that same year. ${ }^{74}$ The initiative came from its director Johann Anton Ke(h)rnhofer ${ }^{75}$ the Fragamt he proposed was to serve as a sales agency, a lost property office, an employment agency and as an information service in commercial matters. ${ }^{76}$ In 1755 , the Fragamt started its operations and announced in a printed Avertissement that it not only intended to publish an intelligence paper, but aimed to be a comprehensive information centre as well. ${ }^{77}$

Over the following decades, the Mährische Lehenbank and the Fragamt changed ownership several times. Both institutions were taken over by the Jewish entrepreneur Hönig in 1764, two years before Kernhofer's death on 11 May 1766. When Hönig died in 1767 , they passed to his sons, the Hönig brothers. ${ }^{78}$ After an auction in 1792, the license went to a consortium of three

74 On the Lehenbank, see e.g. Adolf Beer, 'Die österreichische Handelspolitik unter Maria Theresia und Josef II', Archiv für österreichische Geschichte, 86 (1899), pp. 1-204, at 146-51; Jindřich Chylík, 'První obchodní banka u nás', Časopis Matice moravské, 69 (1950), pp. 261-82; Herman Freudenberger, The Industrialization of a Central European City: Brno and the Fine Woollen Industry in the 18th Century (Edington: Selvedge, 1977), pp. 55-62.

75 MZA, B1o Kommerzienkonsess, cart 110, sig L2/1770: Kernhofer to Moravian Gubernium, 23 September 1751, fos. 59-63, at 61v.

76 MZA, B1, cart 2249, sig L16o, dodatky 6o: Nachtrags-Patent, in Betref, der zu Brünn aufgerichteten Lehen-Bank, 25 October 1751, fos. 54-7, at 56 v-57r.

77 Zdeněk Šimeček, 'Časopisy a jejich rozširování na Moravě do počátku 19. Století', in Sborník k 8o. narozeninám Mirjam Bohatcové (Prague: Knihovna Akademie ved Ceské republiky, 1999), pp. 333-46, at 335; MZA, B1, cart 2249, sig L16o, dodatky 61: Avertissement, fo. 44; the Avertissement can be found in the first volume of the Brno KundschaftsblattWochentlicher Intelligenz-Zettel aus dem Frag-Amt der Kayserlich-Königlichen privilegirten Lehen-Bank zu unser lieben Frauen in Brünn (WIZ), Archive Města Brna, Brno (АмB), V13 Knihovna Mitrovského-116 - bound at the front.

78 MZA, B1o Kommerzienkonsess, K6/1766: Report of the Moravian Kommerzienkonsess to the Kommerzienrat, 13 May 1766, fo. 104r; MZA, B14 st Moravské místodržitelství (starší), cart 2410: Adam von Henikstein to Moravian Gubernium, Lviv, 8 June 1791, fos. 971-84, at $971 \mathrm{v}$.

On the Hönig family, see e.g. Leopold Kompert, 'Israel Hönig Edler von Hönigsberg. Biographie', in Kalender und Jahrbuch für Israeliten auf das Schaltjahr (1848) 5608 (Vienna, 1847), pp. 117-44; Ingrid Mittenzwei, Zwischen Gestern und Morgen. Wiens frühe Bourgeoisie an der Wende vom 18. zum 19. Jahrhundert (Bürgertum in der Habsburgermonarchie, 7) (Vienna, Cologne, Weimar: Böhlau 1998), pp. 72, 170-8o, 257; F. Bernd, Die Familien Hönig, Henikstein, Hönigsberg, Hönigshof, "v." Bienenfeld, Bienenfeld und Cappe in genealogischer und historischer Betrachtungsweise, $\mathrm{PhD}$ thesis (University of Vienna, 2002); Christian Hlavac, 'Die Henikstein-Villa und ihr Park in Ober-Döbling', Wiener Geschichtsblätter, 64.1 (2009), pp. 38-56. 
Brno tradesmen-Abraham Greisinger, Johann Herring and Joseph Vinzenz Müller; they held the privilege until 1811, when the Moravian Estates took over the direction of both institutions. ${ }^{79}$

In the early years, the Kundschaftsblatt was published under the title Wochentlicher Intelligenz-Zettel aus dem Fragamte der Kayserlich-Königlichen privilegirten Lehen-Bank zu unser lieben Frauen in Brünn (Weekly intelligence sheet from the Fragamt of the I. R. privileged Lehen-Bank ...). Its headings initially conformed to the customs of intelligence papers at the time, but starting with the Seven Years' War, reports on the course of the war were printed as a supplement: the intelligence paper became a regular political newspaper, which in 1778 became the Brünner Zeitung, published twice weekly and praised for its quality by the authorities. ${ }^{80}$

Very little is known about the brokerage activities that actually took place at the Brno Fragamt. There is reliable evidence that during the first years, its premises as well as those of the Lehenbank were used as an outlet for goods; the Fragamt also taught agricultural knowledge and made silkworm seeds available for free. ${ }^{81}$ Employment agency activities were rare, and thus the main activity of the Brno Fragamt was the publication of the Brünner Zeitung. A project submitted to the Habsburg authorities by a certain Friedrich August Freiherr von Locella in 1815-16, an "AddressComtoir for all products of the mind, the Arts and the efforts of the industries", was not realised. ${ }^{82}$

79 MZA, B14 st, cart 2410: Hofdekret, 30 March 1793, fo. 740; Patent, 5 October 1793, fo. 581-7; MZA, A8, cart. 643, sig. L12: protocol, 22 January 1811, fo. 3or.

8o On this publication, see Jaromír Zeman, 'Zu sprachlichen Entwicklungstendenzen in den Brünner Regionalzeitungen', in Deutschsprachige Zeitungen in Mittel- und Osteuropa, ed. Jörg Riecke and Britt M. Schuster (Berlin: Weidler Verlag 2005), pp. 311-28; Jaromír Zeman, "Zur Textsorte "Suchanzeige" im Brünner "Wochentlichen Intelligenz-Zettel" vom Jahre 1755', in Iva Kratochvilovà, Germanistik im Spiegel der Generationen (Opava: Slezskà University, 2004), pp. 45-58; Zdeněk Šimeček, 'Zeitungen in den böhmischen Städten im 18. Jahrhundert', in Städtische Kultur in der Barockzeit, ed. Wilhelm Rausch (Linz: Der Arbeitskreis, 1982), pp. 263-76; praise of its quality: MZA, B14 st, cart 2410: Moravian Gubernium to Hofkammer, 21 July 1791, fo. 951v.

81 Cf. e.g. WIZ 27 March 1756, no. 13; 3 April 1756, no. 14; 6 May 1762, no. 18; 24 March 1763, no. 12; 31 March 1763, no. 13; 7 April 1763, no. 14.

82 ÖStA, FHKA, NHK, Kommerzkammer, red no. 1144, 49 ex Jan 1815; 63 ex July 1815; 20 ex January 1816; АM B, A1/13 Stará Spisovna Politico-publica, Stara sign. 4199, kr 232: Report of the Brno Magistrate to the Moravian Kreisamt, 10 May 1815: AddresComtoir für alle Erzeugnisse des Geistes, der Kunst und des Gewerbfleißes. 


\section{Conclusion}

Another wave of newly established Fragämter in the Habsburg monarchy followed in the 1780 s. Thus, in 1781, Anton Martin started a Fragamt in Bratislava, as did Johann Friedrich Schütz in Lviv in 1782 and Kaspar Heindl in Graz in 1783; in 1788, the Pest Fragamt opened for business, and in Innsbruck, the Fragamt founded by the journalist Michael Hermann Ambros started operations in 1799. With these institutions, the publication of an advertisement paper or a newspaper was usually the main activity, while local brokerage activities at the premises of the Fragamt remained marginal — with the notable exception of Bratislava. ${ }^{83}$

These intelligence offices may perhaps be regarded as a transitional phenomenon between feudal and capitalist conditions: the sales contracts brokered by them were no longer based on a personal relationship between buyers and sellers, but, at the same time, they were not yet activities in a 'supra-local, time-independent, supra-personal permanent marketplace'. ${ }^{84}$

With the rise of the popular press, many of their functions which formerly took place locally, at the premises of the offices themselves, were taken over by the advertising sections of daily newspapers. The universal pretence of offering information brokerage services for all fields of human life was to yield, by the mid-nineteenth century at the latest, to specialised institutions like servant and tourism agencies, and information offices were forgotten. Only in the most recent present time, these institutions have resurfaced as part of a history of searching and finding, and may be understood as part of the prehistory of search engines like Google. ${ }^{85}$

83 Tantner, Adressbüros, 139-65; Tantner, 'Das Pressburger Frag- und Kundschaftsamt des Anton Martin, 1781-1783, Hungarian Studies, 25.1 (2011), pp. 127-42 <http://dx.doi .org/10.1556/HStud.25.2011.1.11> [8/1/15].

84 See e.g. the account in Laurence Fontaine, 'Bemerkungen zum Kaufen als soziale Praxis. Feilschen, Preise festlegen und Güter ersteigern im frühneuzeitlichen Europa', Historische Anthropologie 14 (2006), pp. 334-48; quotation: Heidrun Homburg, 'Werbung-“eine Kunst, die gelernt sein will". Aufbrüche in eine neue Warenwelt 1750-1850', Jahrbuch für Wirtschaftsgeschichte, 1 (1997), pp. 11-52, at 41.

85 As a first approach to such a prehistory, see Tantner, 'Before Google: A Pre-History of Search Engines in Analogue Times', in Society of the Query Reader: Reflections on Web Search, ed. René König and Miriam Rasch (Amsterdam: Institute of Network Cultures, 2014), pp. 121-38; Thomas Brandstetter, Thomas Hübel and Anton Tantner, eds., Vor Google. Eine Mediengeschichte der Suchmaschine im analogen Zeitalter (Bielefeld: Transcript, 2012). 